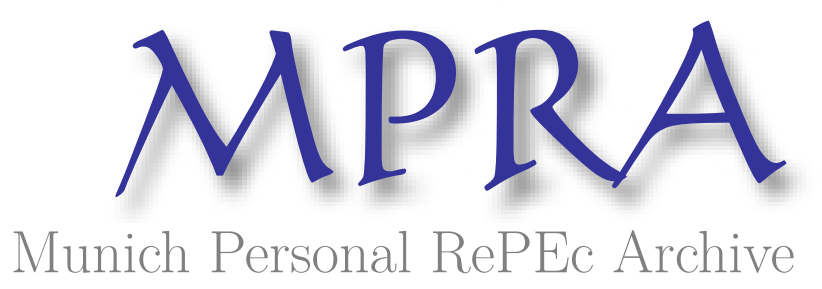

\title{
Have economic growth and institutional quality contributed to poverty and inequality reduction in Asia?
}

Perera, Liyanage Devangi H. and Lee, Grace H.Y.

Monash Univeristy, Monash University

4 June 2013

Online at https://mpra.ub.uni-muenchen.de/52763/

MPRA Paper No. 52763, posted 09 Jan 2014 12:45 UTC 


\title{
Have Economic Growth and Institutional Quality Contributed to Poverty and Inequality Reduction in Asia?
}

\author{
By \\ Liyanage Devangi H. Perera \\ Monash University \\ Department of Economics, School of Business, \\ Monash University, Jalan Lagoon Selatan, Bandar Sunway, \\ 46150 Selangor, Malaysia \\ $\&$ \\ Grace H.Y. Lee \\ Monash University \\ Department of Economics, School of Business, \\ Monash University, Jalan Lagoon Selatan, Bandar Sunway, \\ 46150 Selangor, Malaysia
}

\begin{abstract}
While economic growth has been cited as one of the main factors behind the reduction in absolute poverty, the persisting problem of poverty in developing countries has raised doubts about the efficacy of economic growth in its reduction. Recent evidence revealed that growth in Asia has been accompanied by an increase in relative poverty, or income inequality. High income inequality can slow the rate of poverty reduction, and create social unrest and anxiety. The quality of institutions may also influence the extent to which economic growth reduces poverty. This study examines the effects of economic growth and institutional quality on poverty and income inequality in nine developing countries of Asia for the period 1985-2009. The System Generalized Method of Moments $(G M M)$ estimation method is employed to estimate the equations. While economic growth does not appear to have an effect on income inequality, the results confirm that such growth leads to poverty reduction. Although improvements in government stability and law and order are found to reduce poverty, improvements in the level of corruption, democratic accountability, and bureaucratic quality appear to increase poverty levels. Similarly, the results also show that improvements in corruption, democratic accountability, and bureaucratic quality are associated with a worsening of the income distribution. This study recommends that measures taken to improve the level of institutional quality in developing countries of East and South Asia should address the problems of poverty and income distribution, while adopting policies to support informal sector workers who may be affected by institutional reform.
\end{abstract}

Keywords: income inequality, poverty, growth, institution quality

JEL codes: D3, I3, O1 


\section{Introduction}

South Asia, comprising Afghanistan, Bangladesh, Bhutan, India, Maldives, Nepal, Pakistan, and Sri Lanka, has been growing rapidly in recent years. According to the World Bank, the GDP per capita growth rate for South Asia in 2007 before the global financial crisis was around 7.5 per cent.

Growth in developing countries of East Asia (Brunei, Cambodia, China, Indonesia, Laos, Malaysia, Myanmar, Philippines, Thailand, and Vietnam) has also been remarkable, with an average GDP per capita growth rate of 6 per cent in 2007, based on World Bank calculations. Data also shows a clear upward trend in GDP per capita in East and South Asia during the period examined in this study (1985-2009). However, despite its remarkable development over the past few decades, poverty levels in South and East Asia remain very high. Therefore, poverty reduction has taken center stage in the development debate, as the Millennium Development Goal of halving the proportion of people living on less than $\$ 1$ a day by 2015 draws closer.

Among the remedies for improving the poverty situation is economic growth, which has been widely cited as being significant in improving the lives of the poor [1-4]. Many economists argue that economic growth, through increasing per capita incomes or expenditures, can ameliorate the situation of the poor [1-4]. However, this view has been subject to debate for many years as other researchers have contended that growth and globalization have led to increasing income disparities, thereby impeding the rate of poverty reduction $[5,6]$. Hence, it is important to re-examine the relationship between economic growth and poverty in the context of the recent debate on this issue.

As well as re-examining this relationship, it is also imperative to analyze changes in relative poverty or income inequality. Kuznets [7] investigated the relationship between economic development and inequality and found that early stages of development of an economy are characterized by rising inequality, while later stages are associated with lower levels of inequality. This hypothesis suggests that inequality may be rising in developing countries, as these countries are experiencing early stages of economic development. Although several scholars have repudiated this finding [8, 9], attention has recently been paid to rising inequality within countries, especially in the Asian region [10]. Rising inequality is harmful for several reasons. Higher income inequality leads to slower economic growth, particularly in populous countries like China, since greater income inequality can limit the growth of mass demand [11]. Higher inequality also implies that the poor receive a lesser share of the gains from economic growth [12]. If inequality had remained stable in the Asian economies that in reality had witnessed an increase, the same growth in 1990-2010 could have lifted about 240 million more people out of poverty [10]. Finally, income inequality might 
induce the poor to engage in disruptive activities such as crime and riots, creating social unrest and anxiety [13].

At the same time, it is also possible that the rate at which poverty reduces is affected by the quality of institutions in East and South Asian countries [14-16]. This study defines institutions as the formal and informal 'rules of the game' of a society [17, 16]. According to Sala-i-Martin [18], the measures of institutions should encompass the enforcement of contracts, protection of property rights, the predictability and effectiveness of the judiciary system, the level of corruption, the level of transparency of the public administration, and pro-market regulations. This current study uses five subjective measures of institutions, in line with studies by Chong and Caldéron [19, 14], Chong and Gradstein [15], Hasan et al. [17], and Tebaldi and Mohan [16]. These measures are: government stability; corruption (in government); law and order; democratic accountability; and bureaucratic quality. The definitions of these measures are given in Section 3.1.

Institutional quality is said to influence the level of poverty through market inefficiencies and misallocation of resources [16]. Keefer and Knack [20] maintained that poor institutional quality undermines the security of property rights. Taking bureaucratic quality as an example, the poor quality of administrative officials coupled with few institutional restrictions on them lead to greater error in administrative decision-making. This lowers the predictability of government decisionmaking, thereby reducing the security of property and contractual rights [20]. Uncertainty with regard to property rights can deter foreign investment and lead to lower economic growth, which in turn may lower the rate at which poverty is reduced. Weak institutions can have a detrimental effect on inequality as well $[19,15]$. For example, the beneficiaries of tax evasion and tax exemptions (as a result of corruption) are most likely to be relatively wealthy, which means that almost the entire tax burden falls on the poor [21]. While most studies have examined institutional quality and its effect on poverty and income inequality for countries across several regions, empirical research on the Asian region is lacking. Thus, examination of a particular region is important, as there could be regional and cultural differences in the nature of institutions.

The purpose of this study, therefore, is to examine the effects of economic growth and improvements in the quality of institutions on poverty and income inequality in East and South Asia, for the period 1985 to 2009, using the system Generalized Method of Moments (GMM) estimation method. The analysis is conducted for nine developing countries in the region - China, Indonesia, Malaysia, Philippines, and Thailand (East Asia), and Bangladesh, India, Pakistan, and Sri Lanka (South Asia). Specifically, this study aims to answer the following questions: 
1. To what extent has economic growth led to a reduction in poverty in East and South Asia?

2. Does economic growth lead to higher income inequality?

3. Has the level of institutional quality had an influence on poverty reduction?

4. What is the effect of institutions on income inequality?

The rest of this paper is organized as follows. Section 2 examines the levels of poverty, inequality, and institutional quality in East and South Asia, as well as the past and present literature on the relationships between growth, institutions, and poverty and inequality. Section 3 presents details of the data used and the econometric approaches employed in the present study. Empirical findings and the analysis and discussion of the results are presented in Section 4. The paper concludes with a summary of the research findings and policy recommendations.

\section{2. $\quad$ Literature Review}

\subsection{The relationship between growth and poverty}

An examination of the poverty situation in East Asia shows that even though the percentage of people living on less than $\$ 1.25$ per day fell from 54.7 per cent in 1990 to 16.8 per cent in 2005 (a reduction of 37.9 percentage points), China alone accounted for 85 per cent of this reduction [22]. Progress in other East Asian countries was relatively much slower. Poverty reduction has been even more subdued in the South Asian region. Although the percentage of the poor in South Asia was around the same level as in East Asia in 1990 at 51.7 per cent, it had fallen to only 40.3 per cent by 2005 (a reduction of 11.4 percentage points) [22]. Table 1 demonstrates the changes in the average poverty level (calculated over five-year periods and measured by four different types of poverty measures: headcount index, poverty gap index, squared poverty gap index, and Watts index) over the period 1985 to 2009 in East and South Asia. With the exception of Pakistan and Sri Lanka, South Asia has been far less successful in reducing poverty compared to East Asia. Poverty reduction has been slow in India, while Bangladesh reports an increase in poverty levels over the period observed. Hence, it is clear that poverty reduction remains a significant challenge for East and South Asia.

Among the remedies for improving the poverty situation, economic growth has been alleged to be significant in reducing poverty. Dollar and Kraay's [3] research is one of the key studies supporting this argument. Their findings reveal that growth can be expected to raise the incomes of the poor and reduce poverty, suggesting that growth-enhancing policies and institutions would provide equal 
Table 1: Measures of poverty and income inequality for nine countries of East and South Asia, over five-year periods, 1985-2009

\begin{tabular}{|c|c|c|c|c|c|c|c|c|c|c|c|}
\hline & & & BGD & IND & PAK & LKA & $\mathrm{CHN}$ & IDN & MYS & PHL & THA \\
\hline \multirow{5}{*}{ 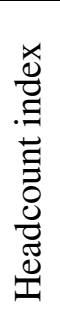 } & & 1985-1989 & 47.77 & 51.55 & 66.46 & 19.96 & 40.96 & 66.28 & 2.15 & 32.69 & 17.20 \\
\hline & & 1990-1994 & 52.70 & 46.62 & 44.29 & 15.01 & 46.54 & 52.52 & 1.62 & 29.40 & 5.45 \\
\hline & & 1995-1999 & 49.55 & 46.62 & 38.60 & 16.32 & 35.26 & 44.28 & 1.31 & 21.61 & 1.14 \\
\hline & & $2000-2004$ & 56.11 & 40.00 & 29.23 & 13.95 & 23.33 & 28.80 & 0.54 & 22.22 & 0.84 \\
\hline & & 2005-2009 & 50.47 & 31.61 & 21.81 & 7.04 & 12.75 & 23.45 & 0.00 & 20.52 & 0.58 \\
\hline \multirow{5}{*}{ 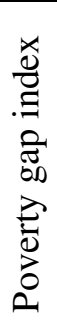 } & & 1985-1989 & 12.44 & 15.35 & 23.93 & 4.30 & 13.27 & 22.72 & 0.33 & 9.21 & 3.43 \\
\hline & & 1990-1994 & 14.75 & 12.86 & 13.71 & 2.71 & 17.32 & 15.35 & 0.14 & 8.09 & 0.40 \\
\hline & & 1995-1999 & 14.01 & 12.86 & 8.99 & 2.96 & 12.52 & 11.72 & 0.16 & 5.25 & 0.05 \\
\hline & & $2000-2004$ & 17.27 & 10.41 & 6.14 & 2.64 & 7.08 & 5.94 & 0.06 & 5.50 & 0.03 \\
\hline & & 2005-2009 & 14.17 & 7.46 & 3.78 & 0.98 & 3.17 & 5.05 & 0.00 & 4.60 & 0.09 \\
\hline \multirow{5}{*}{ 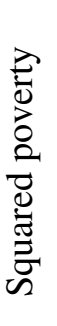 } & \multirow{5}{*}{ 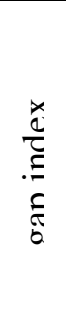 } & 1985-1989 & 4.44 & 6.11 & 11.08 & 1.39 & 6.08 & 10.05 & 0.09 & 3.43 & 0.92 \\
\hline & & 1990-1994 & 5.66 & 4.80 & 5.97 & 0.80 & 8.64 & 5.98 & 0.02 & 2.92 & 0.04 \\
\hline & & 1995-1999 & 5.18 & 4.80 & 2.98 & 0.80 & 6.09 & 4.27 & 0.03 & 1.68 & 0.00 \\
\hline & & $2000-2004$ & 6.86 & 3.73 & 1.90 & 0.75 & 2.90 & 1.76 & 0.01 & 1.80 & 0.00 \\
\hline & & 2005-2009 & 5.20 & 2.54 & 0.99 & 0.22 & 1.15 & 1.58 & 0.00 & 1.37 & 0.02 \\
\hline \multirow{5}{*}{\multicolumn{2}{|c|}{ 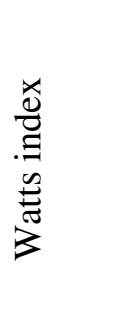 }} & 1985-1989 & 0.161 & 0.201 & 0.331 & 0.053 & 0.189 & 0.311 & 0.004 & 0.120 & 0.040 \\
\hline & & 1990-1994 & 0.189 & 0.166 & 0.189 & 0.032 & 0.256 & 0.202 & 0.001 & 0.105 & 0.005 \\
\hline & & 1995-1999 & 0.182 & 0.166 & 0.111 & 0.034 & 0.182 & 0.149 & 0.002 & 0.067 & 0.001 \\
\hline & & 2000-2004 & 0.229 & 0.133 & 0.074 & 0.030 & 0.095 & 0.070 & 0.001 & 0.071 & 0.000 \\
\hline & & 2005-2009 & 0.180 & 0.090 & 0.045 & 0.010 & 0.039 & 0.061 & N/A & 0.058 & 0.001 \\
\hline \multirow{5}{*}{\multicolumn{2}{|c|}{$\begin{array}{l}\underset{0}{0} \\
. \Xi \\
. \Xi \\
. \Xi\end{array}$}} & $1985-1989$ & 27.89 & 32.85 & 33.35 & 32.47 & 24.83 & 30.26 & 46.61 & 40.84 & 43.84 \\
\hline & & 1990-1994 & 27.60 & 31.47 & 31.77 & 32.48 & 29.50 & 30.61 & 47.65 & 43.36 & 46.22 \\
\hline & & 1995-1999 & 33.46 & 31.47 & 30.84 & 35.41 & 31.74 & 31.29 & 48.84 & 46.16 & 42.76 \\
\hline & & 2000-2004 & 33.46 & 34.03 & 30.79 & 41.06 & 35.74 & 30.39 & 37.91 & 45.29 & 42.52 \\
\hline & & 2005-2009 & 33.22 & 34.62 & 31.38 & 40.26 & 36.30 & 33.46 & 46.11 & 43.51 & 40.96 \\
\hline
\end{tabular}

Note: 1. BGD=Bangladesh, IND=India, PAK=Pakistan, LKA=Sri Lanka, CHN=China, IDN=Indonesia, MYS=Malaysia, PHL=Philippines, THA=Thailand.

2. Headcount index measures the share of the population with income/consumption per person below the poverty line ( $\$ 1.25$ a day). Poverty gap index is the mean distance from the poverty line as a proportion of the poverty line. Squared poverty gap index is the mean of the squared distances from the poverty line as a proportion of the poverty line. Watts index is the mean across the population of the proportionate poverty gaps where the poverty gap is the log of the ratio of the poverty line to income (the poverty gap of the nonpoor is equal to zero). The Gini coefficient is the measure of income inequality and ranges from 0 to 100, with higher values representing higher inequality (PovcalNet, World Bank). 
Source: Authors' calculations based on data from PovcalNet, World Bank.

benefit to the poor as well as everyone else in society. Other studies using panel data from developing countries across regions have also shown that growth is favorable to the poor. Kraay [4] reported that much of the variation in the changes in poverty could be associated with growth in average incomes. His results emphasize the importance of growth in poverty reduction, and suggest that poverty-reducing policies should center on determinants of growth in average incomes such as openness to international trade [4]. Adams Jr.'s [1] findings did not reveal any particular relationship between economic growth and income inequality, implying that poverty should reduce with economic growth.

The size of the growth effect on poverty is still debatable, however. During the 1990s, the growth elasticity of poverty was generally found to range between -2.0 and -3.0 for developing countries around the world [23, 24], although Fosu [25] estimated this value to be between -0.02 and -0.68 using data from the 1990s for a sample of African economies. More recent estimates for developing countries obtained by Bhalla [26] reveal the elasticity to be higher, at around -5.0. Notwithstanding, Fanta and Upadhyay [27] reported this figure to be around -0.5 for 16 African countries using data for 2005, while the figure for South Asia was estimated to be between -0.20 and -0.22 using data from 1990 to 2004 [28]. Hence, it is possible that the elasticity of poverty with respect to economic growth can vary according to region and time period examined; given this, further research is required in this area.

On the contrary, two studies that used the same data as Dollar and Kraay [3] supported the notion that economic growth has not contributed to poverty alleviation. Eastwood and Lipton [29] criticized the findings of Dollar and Kraay [3], asserting that there were numerous exceptions where economic growth has not helped the poor. Drawing on this argument, Donaldson [30] identified positive exceptions (cases in which the incomes of the poorest quintile increased by a larger extent than predicted by overall economic growth) and negative exceptions (cases in which the incomes of the poor increased by far less than the model's prediction based on economic growth rates). He claimed that none of the positive exceptions ranked at the top in terms of the liberal economic policies suggested by Dollar and Kraay [3]. His study concluded that for the negative exceptions, incomes of the poor did not increase despite rapid economic growth. For the positive exceptions, incomes of the poor increased in spite of negative growth [30]. 
Research conducted on a single country has also revealed that there have been instances where growth has not led to poverty reduction. In India, the benefits of economic growth may not have trickled down to the poor when considered over a long time period (1951-1991) [31]. Labor-saving capital formation that accompanied economic growth prevented the latter from reducing poverty. Based on their analysis, Basu and Mallick [31] concluded that it might not be wise to believe that growth will always be accompanied by a fall in poverty levels. Using data from Indonesia, Balisacan et al. [2] did not find evidence of a one-to-one correspondence between average incomes of the poor and overall mean income, and concluded that growth may not be good enough. However, Suryahadi, Suryadarma and Sumarto [32] found that, in Indonesia, agricultural and services growth play major roles in poverty reduction in both urban and rural areas.

Despite popular belief that economic growth is beneficial for the poor, whether economic growth actually reduces poverty remains inconclusive. Indeed, as outlined above, various studies have observed vastly different elasticities of poverty with respect to economic growth. Moreover, previous research has not focused on the Asian region. Hence, the current study aims to contribute to the literature regarding this issue, using data on developing countries in the Asian region. Additionally, it is possible that the elasticity of poverty reduction with respect to economic growth could be different for this region.

\subsection{The relationship between growth and inequality}

According to the ADB [10], widening income disparities in the last two decades have become a growing concern in the Asian region, with about 82 per cent of developing Asia's population living in countries that have become more unequal in terms of the income distribution. Table 1 above also reports the trends in income inequality as measured by the Gini index from 1985 to 2009. It is clear that since 1985 income inequality has increased in six of the nine countries examined, which may be explained using the Kuznets [7] hypothesis.

Since the pioneering work of Kuznets [7] in 1955, the issue of whether economic growth improves or worsens the income distribution has been subject to debate. Kuznets [7] introduced the idea of an inverted U-shaped relationship between economic development and income inequality. His proposition was based on the premise that, as an economy develops, its structure of production shifts from agricultural to industrial. The agricultural and rural sector forms the bulk of the economy and is characterized by low per capita income and low inequality, while the industrial and urban sector starts smaller, has higher per capita income, and higher inequality. As the economy develops and people shift from the agricultural to the industrial sector, those who move see a rise in 
their incomes, thereby raising the level of inequality in the economy. Therefore, at early stages of development, there is a positive relationship between economic growth and inequality. As more workers shift from the agricultural sector to the industrial sector, the reduced supply in the agricultural sector drives up wages in this sector. In addition, those who move to the industrial sector work harder and move up the ladder to attain the income of the richer workers. Inequality falls with later stages of development, resulting in a negative relationship between economic growth and inequality [7, 13]. Hence, based on Kuznets' [7] theory, it is possible to note an inverted Ushaped relationship between economic growth and income inequality.

In order to overcome the weaknesses of cross-sectional and time-series data, studies have also employed panel data and found evidence to support the Kuznets [7] hypothesis. Jha [33] stated that the hypothesis could be applied to only the developing countries in his sample. Thornton's [34] results indicated that inequality tended to rise at lower levels of income, and subsequently fall with higher income levels. On the other hand, Chambers [35] observed that in the long run growth is accompanied by a decline in inequality in developing countries and rising inequality in developed countries. Similar findings were reported by Riggs, Hobbs, Hobbs and Riggs [36] who found that population-weighted income inequality increased among the richest country groups and decreased in the poorest from 1969 to 2007.

Additionally, studies have observed a positive relationship between economic growth and income inequality, which suggests that it is possible for inequality to increase with the level of economic development. Elbers and Lanjouw [37] sought to understand the distributional consequences of nonfarm sector growth in rural areas of Ecuador. They found that increases in nonfarm incomes tended to increase income inequality. Shahbaz [38] also reported that inequality appears to be positively and significantly associated with economic growth in the short run and long run.

Conversely, a number of studies have shown that growth does not have an effect on the income distribution. Das and Barua [39] did not find evidence of a trade-off between economic growth and income inequality in India, while an important study by Deininger and Squire [40] also supported the notion that economic growth is not associated with rising inequality. As mentioned in Section 2.1, Dollar and Kraay [3] asserted that the incomes of the poor tended to rise equi-proportionately with growth in average incomes, which promotes the idea that growth may leave the income distribution unchanged. Ravallion [41] noted that there was no significant correlation between growth in survey mean income and changes in inequality. 
Notwithstanding the multitude of studies that have investigated the effect of economic growth on income inequality, it cannot be claimed that they point towards a common and definite answer. Hence, more research needs to be conducted on the effect of economic growth on the income distribution.

\subsection{The relationship between institutions and poverty}

Table 2 presents the scores of the five institutional measures for selected years employed in this study. The maximum score for each measure varies (refer to Section 3.1), while the minimum score for all five measures is zero. Higher scores represent better institutional quality. An examination of the regional median for East and South Asia reveals that the indices have decreased over the years, which indicates that the quality of institutions is worsening. An exception is the democratic accountability index for East Asia, where the scores have improved over the period 1998 to 2010. For South Asia scores have fallen for three institutional measures, while for East Asia it is only for two measures. However, a comparison of scores for South Asia against those of East Asia shows that by 2010 South Asia outranked East Asia in three of the five institutional indices (government stability, corruption, and law and order), while East Asia performed better only on the democratic accountability index, with the bureaucratic quality scores being the same for East Asia and South Asia. Thus, both East and South Asia have much to do about the problem of worsening institutional quality.

Very few studies have examined the relationship between institutions and poverty. Among them, Chong and Caldéron [14] investigated the effect of five alternative measures of institutions on the degree, severity, and incidence of poverty. The authors reported that the higher the quality and efficiency of a country's institutions, the lower the level, incidence, and severity of poverty. However, their study could be subject to endogeneity issues as the authors used the 'share of government spending on defense' as an instrument for institutions, which could be directly correlated with poverty [16]. Furthermore, lagged variables such as income inequality and fertility rates used in Chong and Caldéron's [14] study are auto-correlated and correlated with the error term, making the estimates biased [16]. Tebaldi and Mohan [16] found a negative relationship between institutions and poverty using the Instrumental Variable method for 53 countries across several regions. Their findings suggested that control of corruption, regulatory quality, rule of law, and government effectiveness have a stronger, negative impact on poverty compared to voice and accountability. Political stability does not appear to have an impact on poverty reduction, while expropriation risk is only marginally significant. Gupta, Davoodi and Alonso-Terme [42] concluded that corruption has a detrimental effect on the income growth of the poor, where the poor are 
Table 2: Measures of institutional quality for nine countries of East and South Asia, 1998-2010

\begin{tabular}{|c|c|c|c|c|c|c|c|c|c|c|c|c|c|c|c|}
\hline & \multicolumn{3}{|c|}{ Government Stability } & \multicolumn{3}{|c|}{ Corruption } & \multicolumn{3}{|c|}{ Law and Order } & \multicolumn{3}{|c|}{$\begin{array}{c}\text { Democratic } \\
\text { Accountability }\end{array}$} & \multicolumn{3}{|c|}{ Bureaucratic Quality } \\
\hline & 1998 & 2004 & 2010 & 1998 & 2004 & 2010 & 1998 & 2004 & 2010 & 1998 & 2004 & 2010 & 1998 & 2004 & 2010 \\
\hline Bangladesh & 9.58 & 10.21 & 9.04 & 2.00 & 1.04 & 3.00 & 3.25 & 1.04 & 2.33 & 5.00 & 2.75 & 3.50 & 2.00 & 2.00 & 2.00 \\
\hline India & 8.83 & 8.33 & 8.42 & 3.00 & 2.21 & 2.50 & 4.00 & 4.00 & 4.00 & 5.00 & 6.00 & 6.00 & 3.00 & 3.00 & 3.00 \\
\hline Pakistan & 10.17 & 9.42 & 5.83 & 3.00 & 1.50 & 2.00 & 3.00 & 3.00 & 3.42 & 3.00 & 1.00 & 2.67 & 2.00 & 2.00 & 2.00 \\
\hline Sri Lanka & 9.25 & 6.67 & 8.92 & 4.00 & 3.00 & 2.50 & 3.00 & 3.00 & 2.83 & 5.00 & 4.17 & 3.46 & 2.00 & 2.00 & 2.00 \\
\hline Regional Median & 9.42 & 8.88 & 8.67 & 3.00 & 1.85 & 2.50 & 3.13 & 3.00 & 3.13 & 5.00 & 3.46 & 3.48 & 2.00 & 2.00 & 2.00 \\
\hline China & 11.17 & 11.00 & 10.25 & 2.00 & 2.00 & 2.00 & 5.00 & 4.50 & 4.08 & 1.00 & 1.00 & 1.50 & 2.00 & 2.00 & 2.00 \\
\hline Indonesia & 7.92 & 7.21 & 7.75 & 1.25 & 1.00 & 3.00 & 2.50 & 2.67 & 3.00 & 1.00 & 4.83 & 5.00 & 2.00 & 2.00 & 2.00 \\
\hline Malaysia & 9.25 & 10.63 & 6.88 & 3.75 & 2.50 & 2.50 & 4.92 & 3.67 & 4.00 & 3.33 & 3.92 & 4.50 & 3.00 & 3.00 & 3.00 \\
\hline Philippines & 10.25 & 8.88 & 6.50 & 3.42 & 2.00 & 2.00 & 4.00 & 2.00 & 2.50 & 6.00 & 5.00 & 5.00 & 3.00 & 3.00 & 3.00 \\
\hline Thailand & 9.25 & 9.67 & 6.38 & 2.00 & 1.50 & 2.00 & 5.00 & 2.50 & 2.50 & 4.00 & 4.00 & 4.50 & 2.00 & 2.00 & 2.00 \\
\hline Regional Median & 9.25 & 9.67 & 6.88 & 2.00 & 2.00 & 2.00 & 4.92 & 2.67 & 3.00 & 3.33 & 4.00 & 4.50 & 2.00 & 2.00 & 2.00 \\
\hline
\end{tabular}

Source: International Country Risk Guide (ICRG) dataset, The Political Risk Services Group 
defined as those at the bottom 20 per cent of the income distribution. According to their results, a one-standard deviation increase in the growth rate of corruption is associated with a 1.6 percentage point reduction in the income growth of the poor.

Some studies that have explored this relationship, however, have observed different results. For example, Hasan et al. [17] reported that the governance variable appears to be insignificant in the poverty regressions (where governance is the principal components aggregation of rule of law, government efficiency, and control of corruption). Nevertheless, the coefficient of the governance variable always took a negative value, suggesting that better governance is more likely to be associated with lower poverty levels. Tebaldi and Mohan [16], however, raised doubts about these findings as they could have been affected by endogeneity issues. The use of several alternative measures of institutions such as governance, political freedom, and ease of doing business could have introduced the problem of multicollinearity, thereby inflating the covariance estimates and leading to Type-I error [16].

As outlined above, studies that examined this issue obtained data from countries across several regions. However, it would be of interest to examine institutional quality and its effect on poverty in developing countries of a particular region, since there could be regional and cultural differences associated with the nature of institutions. To the authors' knowledge, no studies pertaining to this topic seem to have focused on the Asian region.

\subsection{The relationship between institutions and inequality}

It is widely believed that poor institutional quality has a detrimental effect on income inequality. For instance, corruption can alter the composition of social spending to benefit the rich at the expense of the poor, leading to higher inequality [21]. In line with this argument, studies have found a positive relationship between institutions and income inequality. Chong and Gradstein [15] showed that weaker institutional quality leads to higher income inequality. Gyimah-Brempong [43] examined the effect of corruption on income inequality in selected African countries, and reported that higher corruption had an adverse effect on the income distribution. Further, Gyimah-Brempong and de Camacho [44] pointed out that the 'degenerative' nature of corruption practiced typically in African and Latin American countries has a much more deleterious effect on the income distribution, compared to the 'developmental' corruption found in Asia.

On the contrary, other studies have asserted that the relationship between income inequality and institutions takes an inverted U-shape. Chong and Caldéron [19] found that in developing countries 
improvements in the quality of institutions would be associated with higher income inequality, while in developed countries such improvements would lead to a more equitable income distribution. $\mathrm{Li}, \mathrm{Xu}$, and Zou [45] affirmed that there is an inverted U-shaped relationship between corruption and income inequality. Based on their results, inequality appears to reduce with further reductions in the level of corruption, but only when the corruption index exceeds 2.91 (a higher corruption index indicates lower corruption levels). Similarly, Andres and Ramlogan-Dobson [21] supported the notion that there could be a trade-off between corruption and income inequality in Latin America, with a lower level of corruption leading to higher income inequality.

It appears that the empirical evidence on the institutions-inequality relationship is mixed; hence, it may not be possible to draw a conclusion on the effect of institutional quality on the income distribution. Additionally, here again, prior studies that have examined the institutions-income inequality relationship obtained data from countries across several regions, with no studies focusing on the Asian region in particular.

\section{Methodology}

This study investigates the following equations:

$$
\begin{aligned}
& P(\omega)_{i, t}=\alpha_{0}+\alpha_{1} P(\omega)_{i, t-1}+\alpha_{2} Y_{i, t}+\alpha_{3} T(s)_{i, t}+\varepsilon_{1 i, t} \\
& I_{i, t}=\beta_{0}+\beta_{1} I_{i, t-1}+\beta_{2} Y_{i, t}+\beta_{3} T(s)_{i, t}+\varepsilon_{2 i, t}
\end{aligned}
$$

where $P_{i, t} \quad=$ Poverty measure in country $i$, as measured by $\omega$ (corresponding to: headcount index, poverty gap index, squared poverty gap index, and Watts index),

$I_{i, t} \quad=$ Gini coefficient for country $i$,

$Y_{i, t} \quad=$ Real GDP per capita growth rate of country $i$,

$T_{i, t} \quad=$ Institutional quality measure for country $i$, as measured by $s$ (corresponding to: overall institutional quality, government stability, corruption, law and order, democratic accountability, and bureaucratic quality).

\subsection{Data}

GDP growth is measured as the growth rate in real GDP per capita at Purchasing Power Parity (PPP) in constant 2005 international dollars, obtained from the World Bank. The bulk of existing literature on poverty, inequality, and growth has used this measure for economic growth, thereby enabling a comparison of past results with those of this study. The present study uses the five 
alternative indices of institutions employed in Chong and Gradstein's [15] study, drawn from the Political Risk Services’ International Country Risk Guide (ICRG) dataset [46]:

- Government Stability - An assessment of the government's ability to execute its declared programs, as well as its ability to stay in office (Maximum score: 12 points)

- Corruption - An assessment of the level of corruption within the political system (Max score: 6 points)

- Law and Order - This index measures two components - Law and Order. The Law subcomponent measures the "strength and impartiality of the legal system", while the Order subcomponent is an assessment of the "popular observance of the law" [46] (Max score: 6 points)

- Democratic Accountability - An assessment of how well the government responds to its people (Max score: 6 points)

- Bureaucratic Quality - An assessment of the strength and expertise of the bureaucracy to "govern without drastic changes in policy or interruptions in government services" [46]. In countries that score well on this index, the bureaucracy tends to be autonomous from political pressure. (Max score: 4 points)

The minimum number of points that can be given to all five measures is zero. For all institutional indices, higher scores represent better institutional quality, and vice versa. Following Chong and Caldéron [19], a composite score representing the overall level of institutional quality is also calculated. This variable gives equal weight to all five institutional measures and is re-scaled from zero to six, with higher values representing better institutional quality.

The poverty data is obtained from the World Bank's PovcalNet, which is a computational tool that calculates poverty and inequality measures based on different international poverty lines. To allow for comparability of the level of poverty and income inequality across countries, this study uses an international poverty line of $\$ 1.25$ per day in 2005 PPP exchange rates. The $\$ 1.25$ a day poverty line is the mean of the national poverty lines of the poorest 15 countries. Although the $\$ 2$ a day poverty line conforms to the typical poverty lines of middle-income countries, the panel unit root tests showed that the poverty data which was based on this poverty line was $I(2)$ rather than $I(1)$. Therefore, the $\$ 1.25$ per day international poverty line was selected, which was also used in the study of Ravallion [12].

The poverty measures that are used in this study are the Foster-Greer-Thorbecke class of measures that take the form, 
where $x$ is a non-negative parameter, $z$ is the poverty line, and $y_{i}$ is the income of the $i^{\text {th }}$ poor [14]. When $x=0, P$ is referred to as the headcount index, when $x=1$, it is known as the poverty gap index, and when $x=2$, it is referred to as the squared poverty gap index. These three poverty indices have been employed in several other studies such as those by Adams Jr. [1], Adams Jr. and Page [47], Balisacan [48], and Chong and Caldéron [14].

The main poverty measure used in this study is the headcount index. This index measures the share of the population whose income is below the poverty line and is an indication of the 'prevalence' of poverty. However, an increase in the incomes of the poor that does not bring them above the poverty line will not reduce the headcount index [4]. In addition, the headcount index does not consider how far the poor are from the poverty line [47]. Therefore, two additional poverty measures - poverty gap and squared poverty gap indices - are employed, and their results are reported as sensitivity analysis. The poverty gap index is a measure of the 'depth' of poverty, as it measures how far the average incomes of the poor are from the poverty line. However, this measure does not consider the distribution of income among the poor. The squared poverty gap index overcomes this limitation. It is sensitive to changes in the distribution of income among the poor, and thus is a measure of the 'severity' of poverty.

The Watts index is also used as a measure of poverty in this study. It is a useful poverty measure since it satisfies three axioms possessed by any good measure of poverty (and which are not satisfied by the Foster-Greer-Thorbecke class of measures) [49]. These three axioms are: (1) the measure does not change when incomes of the non-poor change; (2) an income loss suffered by the poor increases the poverty measure; and (3) inequality-reducing transfers among the poor reduce the poverty measure [49]. PovcalNet also reports the Gini coefficient, which is the measure of income inequality that is used in this study. It is scaled to lie between zero and one hundred with larger coefficient values representing higher degrees of income inequality.

As mentioned in Section 1, this study focuses on nine developing countries from East and South Asia. Other developing countries from the region have been excluded due to lack of poverty and income inequality data. This study examines poverty, income inequality, growth, and institutional quality data for the period 1985 to 2009 . To account for short-run disturbances in the data, especially for GDP per capita, the data for all variables are averaged over five-year periods as 
conducted in the studies of Dollar and Kraay [3] and Forbes [50]. That is, the averages are calculated for 1985-1989, 1990-1994, 1995-1999, 2000-2004, and 2005-2009.

\subsection{The Generalized Method of Moments (GMM) estimation}

Panel data has several important advantages over the conventional cross-sectional or time-series data [51]. Since panel data involves a larger number of data points, it offers more degrees of freedom and reduces collinearity among the independent variables. Hence, it can improve the efficiency of econometric estimates [51]. However, the use of panel data in this study can introduce the problem of heteroscedasticity and autocorrelation into the model. Owing to heterogeneity in the characteristics of different countries, it is likely that the error-variance will not be constant across observations. The explanatory variables are also possibly endogenous and, including the lagged dependent variable on the right hand side of Equations 1 and 2, may lead to correlation between this variable and the first-differenced error [52]. In other words, since $P_{i, t}$ and $I_{i, t}$ are functions of $\eta_{i}, P_{i, t-}$ 1 and $I_{i, t-1}$ will also be functions of $\eta_{i}$. Hence, the lagged dependent variables will be correlated with the error term, resulting in biased and inconsistent estimators if the OLS estimation method is used [52]. The standard estimation methods using panel data are fixed effects or random effects, but neither of these methods can be used in this study since Equations 1 and 2 contain a lagged endogenous variable (poverty and inequality measure) [50].

Hence, by employing GMM estimators suggested by Arellano and Bond [53] to estimate Equations 1 and 2, this study overcomes the abovementioned problems that could arise in dynamic panel data models. The dynamic panel approach improves on previous efforts to examine the effect of growth and institutions on poverty and inequality in the following ways: (1) panel estimation permits exploitation of the time-series and cross-sectional nature of the dynamic relationships between economic growth, institutional quality, poverty and income inequality; (2) in instrumental variable regressions involving purely cross-country data, the error term includes any unobserved countryspecific effects, which may result in biased coefficient estimates; and (3) the GMM estimator helps to control for possible endogeneity of all the independent variables. This dynamic panel estimator does not require the error term to take any particular distributions. Thus, GMM estimators produce efficient and consistent estimates even in the presence of heteroscedasticity. 


\subsection{Panel unit root tests}

Identification of the parameters would not be possible or the parameters will be weak if the series are random walks or near unit root processes. The use of the first-differenced GMM estimator can, therefore, lead to large finite-sample downward biases [54]. The standard orthogonality conditions under the first-differenced GMM estimator do not hold when the levels series contain unit root [52]. Hence, it is essential that unit root tests are first performed on the series. This study employs the commonly used panel unit root test proposed by Levin, Lin and Chu [55], also known as LLC, which tests the null hypothesis of non-stationarity or the presence of unit root.

The Augmented Dickey Fuller (ADF) test is employed when performing panel unit root tests in order to check for stationarity of the series. LLC considers the following ADF specification:

$\Delta y_{i t}=\alpha_{i}+\gamma_{i} y_{i, t-1}+\sum_{j=1}^{k} \alpha_{j} \Delta y_{i, t-j}+e_{i, t}$

where $y$ is the variable to be tested, $t=1, \ldots, T$ refers to the time periods, and $i=1, \ldots, N$ denote the members of the panel [55]. The lag lengths, $k$, are chosen based on three different information criteria: Akaike, Schwarz, and Hannan-Quinn. The $\gamma_{i}$ are restricted to be the same across the crosssections. The null hypothesis for the LLC test can be stated as $\gamma_{i}=\gamma=0$ for all $i$, denoting nonstationarity in the panel data. The alternative hypothesis can be stated as $\gamma_{1}=\gamma_{2}=\ldots=\gamma<0$ for all $i$, indicating that the panel data are stationary.

\subsection{System GMM}

If the panel unit root tests show evidence of non-stationarity in the levels series, then the firstdifferenced GMM estimation method cannot be used. Blundell and Bond [54] proposed the system GMM estimator that uses additional moment restrictions to improve the downward bias caused by near unit root processes. The system GMM estimator exploits "reasonable stationary restrictions on the initial condition processes" which reduces the bias considerably [52, p. 167]. This estimator estimates a set of first-differenced equations that use suitably lagged levels as instruments, as well as levels equations with suitably lagged first-differences as instruments. The system GMM estimator combines the two sets of moment conditions as a linear GMM estimator in a system that contains both first-differenced and level equations [52]. If unit roots are detected in the series, then following Blundell and Bond's [54] framework, this study will use both the levels and the differences of growth, institutional quality, and lagged poverty and income inequality measures as instrumental variables. 
Two specification tests have been suggested by Arellano and Bond [53], and Arellano and Bover [56] to test the validity of the lagged variables as instruments in the regression. The Sargan test of over-identifying restrictions analyzes the sample analog of the moment conditions used in order to test the overall validity of the instruments [15]. This test is very useful in ascertaining whether the instruments chosen are independent of the error term [57]. Failure to reject the null hypothesis indicates that the instruments are not correlated with the error term and, therefore, instrumental variable estimates based on the selected instruments are valid [57]. The second specification test examines whether the differenced error term is first- or second-order serially correlated. In general, the presence of first-order serial correlation is quite likely, even in cases where the error term in levels is uncorrelated, "unless the latter follows a random walk" [15, p. 458]. The failure to reject the null hypothesis of no second-order serial correlation suggests that the error term in levels (the original error term) is serially uncorrelated and that the GMM estimator would be consistent.

\section{4. $\quad$ Results and Discussion}

\subsection{Panel unit root test}

Table 3 presents the results of the LLC panel unit root tests. The series are tested with an individual intercept, and with and without a trend. The tests are also based on three different information criteria: Akaike, Schwarz, and Hannan-Quinn, but only the results based on the Akaike information are presented in Table 3 since all three information criteria gave similar results. For most variables, the null hypothesis of non-stationarity cannot be rejected when the series are in levels, but the null hypothesis of non-stationarity is rejected when the series are first-differenced. Specifically, log differenced GDP, log headcount index, log poverty gap index, log Watts index, log Gini, the corruption index, and the democratic accountability index are consistently $I(0)$ or $I(1)$ whether or not a trend is included. Log squared poverty gap index, and the overall institutional quality, government stability, law and order, and bureaucratic quality indices are either $I(0)$ or $I(1)$ depending on whether the trend is included. These results suggest that all the series are either $I(0)$ or $I$ (1) variables and the conclusion remains the same for all three information criteria.

Since not all the variables are stationary in the levels equations, the first-differenced GMM estimator would not be efficient [52]. First-differenced GMM estimation uses lagged levels as instruments for the first-differenced equations. However, non-stationarity in the levels equations makes lagged levels unsuitable as instruments to be used, since the lagged levels are weakly correlated with subsequent first-differences [52] and can result in large finite-sample downward biases [54]. Hence, the system GMM estimation method is used in the present study. This method 
employs first-differenced instruments, which are stationary.

Table 3: LLC unit root tests (Akaike Information Criteria)

Akaike Information Criterion

\begin{tabular}{lcccc}
\hline & \multicolumn{3}{c}{ Akaike Information Criterion } \\
\cline { 2 - 5 } Series & With Individual Intercept & With Individual Intercept \& Trend \\
\cline { 2 - 5 } & Level & $\begin{array}{c}\text { First } \\
\text { Difference }\end{array}$ & Level & $\begin{array}{c}\text { First } \\
\text { Difference }\end{array}$ \\
\hline Log differenced GDP & $-7.74(3)^{* * *}$ & & $-7.49(2)^{* * *}$ & \\
Log Headcount index $(\$ 1.25$ a day) & $-0.21(3)$ & $-3.27(2)^{* * *}$ & $-0.82(2)$ & $-3.13(2)^{* * * *}$ \\
Log Poverty gap index & $-0.98(3)$ & $-3.08(2)^{* * *}$ & $-0.85(2)$ & $-3.14(2)^{* * *}$ \\
Log Squared Poverty gap index & $-1.22(3)$ & $-2.84(2)^{* * *}$ & $-2.05(2)^{* *}$ & \\
Log Watts index & $-1.35(3)^{*}$ & & $-1.29(2)^{*}$ & \\
Log Gini & $-2.27(3)^{* *}$ & & $-1.32(2)^{*}$ & \\
Institutional Quality & $-3.75(3)^{* * *}$ & & $0.70(2)$ & $-5.47(2)^{* * *}$ \\
Government stability & $-2.78(3)^{* * *}$ & & $-0.69(2)$ & $-8.05(2)^{* * *}$ \\
Corruption & $-1.01(3)$ & $-6.72(2)^{* * *}$ & $-0.62(2)$ & $-4.07(2)^{* * *}$ \\
Law \& Order & $-4.88(3)^{* * *}$ & & $-0.18(2)$ & $-5.44(2)^{* * *}$ \\
Democratic Accountability & $-4.02(3)^{* * *}$ & & $-1.52(2)^{*}$ & \\
Bureaucratic Quality & $-1.55(3)^{*}$ & & $-0.99(2)$ & $-6.41(2)^{* * *}$ \\
\hline
\end{tabular}

Note: ${ }^{* * *},{ }^{* *}$, and ${ }^{*}$ indicates significance at $1 \%, 5 \%$, and $10 \%$ respectively. The figures shown above represent the tstatistics from ADF-tests results and the bracketed figure represents the maximum lag length for each cross-section based on the Schwarz and Hannan-Quinn information criteria.

Source: Authors' calculations based on data from PovcalNet, World Bank and International Country Risk Guide (ICRG) dataset, The Political Risk Services Group.

\subsection{Poverty, growth, and institutions}

Table 4 presents the results of the system GMM estimation for Equation 1 (Section 3) that measures the effect of economic growth and institutional quality on poverty, and the results of the Sargan test and the test for serial correlation. Table 4 also shows the results for the validity of GDP per capita growth and the five institutional measures as instruments. The p-values of the Sargan test lie within the range of around 0.5 and 0.85 , indicating that there is insufficient evidence to reject the null hypothesis of valid instruments. Based on the results of the test for serial correlation, the null hypothesis that the error term in first differences exhibits no first-order serial correlation can be 
Table 4: System GMM estimation results - Headcount index (measure of poverty)

\begin{tabular}{lcccccc}
\hline $\begin{array}{l}\text { Dependent } \\
\text { Variable: }\end{array}$ & $\begin{array}{c}\text { Institutional } \\
\text { Quality }\end{array}$ & $\begin{array}{c}\text { Government } \\
\text { Stability }\end{array}$ & Corruption & $\begin{array}{c}\text { Law \& } \\
\text { Order }\end{array}$ & $\begin{array}{c}\text { Democratic } \\
\text { Accountability }\end{array}$ & $\begin{array}{c}\text { Bureaucratic } \\
\text { Quality }\end{array}$ \\
\hline \multirow{2}{*}{ GDP growth } & $-17.335^{* * *}$ & $-9.863^{* * *}$ & $-5.900^{* * *}$ & $-5.729^{* * *}$ & -2.876 & 9.080 \\
& $(-2.34)$ & $(-3.53)$ & $(-7.22)$ & $(-3.30)$ & $(-0.87)$ & $(1.19)$ \\
Institutional factors & $-0.774^{* *}$ & $-0.088^{* * *}$ & $0.185^{* * *}$ & $-0.214^{* * *}$ & $0.351^{* * *}$ & $3.416^{* * *}$ \\
& $(-2.51)$ & $(-3.66)$ & $(5.09)$ & $(-3.37)$ & $(2.39)$ & $(3.64)$ \\
Sargan (p-value) & 0.788 & 0.622 & 0.554 & 0.606 & 0.840 & 0.812 \\
M1 (p-value) & 0.089 & 0.044 & 0.088 & 0.070 & 0.046 & 0.028 \\
M2 (p-value) & 0.108 & 0.115 & 0.372 & 0.334 & 0.385 & 0.543 \\
\hline
\end{tabular}

Note: ${ }^{*},{ }^{* *}$, and ${ }^{* * *}$ denote significance at $10 \%, 5 \%$, and $1 \%$ respectively. The $M 1$ and $M 2$ test the null of no first-order and no second-order serial correlation in first-differenced residuals.

Source: Authors' calculations based on data from PovcalNet, World Bank and International Country Risk Guide (ICRG) dataset, The Political Risk Services Group.

rejected. However, the null hypothesis that there is no second-order serial correlation cannot be rejected. This result indicates that there is no second-order serial correlation in the error term of the first-differenced equations, and that the GMM estimator would be consistent.

According to the results of the system GMM estimation for Equation 1, there appears to be a negative and statistically significant relationship between GDP per capita growth and poverty. In other words, economic growth may lead to poverty reduction. This finding is consistent with the studies of Adams Jr. [1], Dollar and Kraay [3], and Kraay [4] which concluded that economic growth is beneficial to the poor. Based on the coefficient estimates for GDP per capita growth (with institutional quality measured by the five different measures), the growth elasticity of poverty is estimated to be around -4.207 and -6.094 (using the headcount index as the measure of poverty). Stated differently and holding all else constant, when growth in GDP per capita increases by 10 per cent, poverty is expected to decrease by 42.1 per cent to 60.9 per cent, on average. Adams Jr. [1] reported a lower elasticity of around -2.27 . However, his value was based on data from developing countries from several regions and, therefore, is an average elasticity for the world (excluding Eastern Europe and Central Asia), while the elasticity of poverty obtained in the current study is an average elasticity for the East and South Asian region. Furthermore, the range of -4.21 and -6.09 is consistent with the findings of Bhalla [26], who claimed that the elasticity was around -5.0 for developing countries. System GMM estimations of Equation 1, using different poverty measures as 
the dependent variable (poverty gap index, squared poverty gap index, and Watts index), still reveal that growth does in fact reduce poverty (refer to Appendix 1). When the poverty measure becomes more bottom-sensitive, the elasticity of poverty reduction increases. These findings are consistent with the results of Adams Jr. [23, 1], Dollar and Kraay [3], and Kraay [4].

As mentioned in Section 1.1, China accounted for 85 per cent of the reduction in poverty witnessed in East Asia over the period 1990 to 2005. In order to ascertain whether the value of elasticity obtained was driven by the high rate of reduction in poverty in China, Equation 1 is estimated again after excluding China from the data. The results still show a similar growth in the elasticity of poverty. An examination of the raw data for the headcount index shows that Indonesia and Thailand have also reduced poverty significantly over the period 1985 to 2009.

According to past research, poor institutional quality, as measured by high levels of corruption, weak judicial systems, and poor bureaucratic quality, tends to worsen the poverty situation $[14,16]$. For example, poor bureaucratic quality reduces the efficiency and the speed of allocation of government resources to the poor [14]. Consistent with past literature, the results of the system GMM estimation of Equation 1 using the overall institutional quality measure show that improvements in institutional quality are associated with reductions in poverty levels. However, when institutional quality is further simplified into the five different measures, the system GMM estimation gives mixed results regarding the effect of institutions on poverty. The results reveal that improvements in government stability and law and order will reduce poverty and the findings remain the same regardless of which poverty measure is used (refer to Appendix 1). Hence, only the results for these two institutional measures attest to findings of previous research.

It is possible for improvements in government stability and law and order to reduce poverty. According to the ADB [58], achieving high political stability is essential for creating an enabling environment for economic growth. Political stability is one of the most important factors that determine whether a country is profitable and less risky to invest in. Investors need to be assured that government policies will be continued, they should have confidence in the ability of the government to operate effectively, and should be induced to take risks [58]. Both domestic and foreign investment can be deterred by the threat of political upheaval and of a new regime that could impose penalizing taxes or expropriate capital assets [59]; hence, political instability may discourage both domestic and foreign investment, which in turn could prevent more rapid economic growth and exacerbate poverty [59]. 
Improvements in access to justice can directly increase the incomes of the poor by protecting them from income shocks, and helping them to assert land rights as well as secure inheritance and property rights. It has been noted that non-adherence to rule of law has been a significant impediment to sustainable poverty reduction in Indonesia [60]. National surveys also indicate that in Indonesia, the poor, particularly the women, are hesitant to take action to address legal disputes when they arise. The poor tend to be intimidated by proceedings of formal institutions or encounter linguistic difficulties. Hence, their legal problems may remain unresolved, often resulting in heavy financial losses. According to the World Bank [60], improving access to justice can also strengthen those government mechanisms that are responsible for the delivery of social services to the poor. In contrast, Chong and Caldéron [14] observed that law and order was insignificant in explaining poverty reduction, and concluded that improvements in laws may have little impact on the poor.

Based on the results of the system GMM estimation of Equation 1, it is interesting to find that a reduction in the level of corruption, improvements in democratic accountability, and bureaucratic quality may actually increase poverty. These three institutional variables have a positive and statistically significant relationship with poverty, implying that improvements in these measures tend to worsen poverty levels. Even after replacing the headcount index with the three different poverty indices, corruption, democratic accountability, and bureaucratic quality still have a positive relationship with poverty (refer to Appendix 1). This finding can be attributed to the results obtained from estimating the effect of improvements in institutional quality on income inequality, which is explained in the next sub-section (Section 4.3).

Corruption may not necessarily be harmful for all developing countries. For instance, while several Asian countries such as China and Thailand have high corruption levels, they have experienced outstanding growth rates. Gyimah-Brempong and de Camacho [44] concluded that the effect of corruption on growth and the income distribution may be different according to the region examined. In fact, Wederman [61] argued that the 'developmental' type of corruption found typically in East Asia is less detrimental to growth and poverty, compared to the 'degenerative' type witnessed in Africa, Latin America, and the Caribbean. When public officials use their positions to loot treasury or extort private property, it is referred to as degenerative corruption, while if they provide resources and protect the private industry in return for a share of the profits of political activities, this is known as developmental corruption. In the latter case, the size of the payment the public official receives depends on the size and growth of the profits of the private sector. Therefore, public officials would ensure that policies that enhance economic growth are implemented. On the other hand, degenerative corruption found in Africa degrades the security of 
property rights, leading to capital flight, capital consumption, and eventually, stagnation of the economy [61].

The coefficient estimates of the institutional variables suggest that a one point increase in the indices for government stability and law and order will reduce poverty by around 8.43 per cent and 19.24 per cent, respectively. On the other hand, a one point increase in the corruption index (which signifies a reduction in the level of corruption) and democratic accountability index increases poverty by 20.3 per cent and 42.12 per cent, respectively. The coefficient estimate for the bureaucratic quality index is extremely high. As mentioned in Section 3.1, the bureaucratic quality index measures the strength and expertise of a bureaucracy to rule without having to make drastic changes to policy or having to interrupt government services [62]. A one point increase in the index is expected to increase poverty by more than 100 per cent, holding all else constant. However, an examination of the raw data for the bureaucratic quality index revealed that the index remains relatively unchanged for almost all Asian countries in the model, even when considered over a long time period. The fact that it remains relatively constant implies that it may be hard for countries to observe an improvement in their bureaucratic quality index and, even if the indices do improve, the effect on poverty would be tremendous. It is possible that a change in the bureaucratic quality index implies a shock to the system.

\subsection{Inequality, growth and institutions}

Table 5: System GMM estimation results - Gini index (measure of income inequality)

\begin{tabular}{lcccccc}
\hline $\begin{array}{l}\text { Dependent Variable: } \\
\text { Gini Index }\end{array}$ & $\begin{array}{c}\text { Institutional } \\
\text { Quality }\end{array}$ & $\begin{array}{c}\text { Government } \\
\text { Stability }\end{array}$ & Corruption & $\begin{array}{c}\text { Law \& } \\
\text { Order }\end{array}$ & $\begin{array}{c}\text { Democratic } \\
\text { Accountabilit } \\
\text { y }\end{array}$ & $\begin{array}{c}\text { Bureaucrati } \\
\text { c Quality }\end{array}$ \\
\hline GDP growth & 1.532 & -0.042 & 0.084 & -1.366 & 0.077 & 2.084 \\
& $(0.49)$ & $(-0.04)$ & $(0.15)$ & $(-0.97)$ & $(0.22)$ & $(1.32)$ \\
Institutional factors & 0.080 & 0.007 & $0.062^{*}$ & -0.008 & $0.058^{* * *}$ & $0.305^{* * *}$ \\
& $(0.70)$ & $(0.66)$ & $(1.86)$ & $(-0.227)$ & $(4.32)$ & $(2.70)$ \\
Sargan (p-value) & 0.668 & 0.758 & 0.867 & 0.513 & 0.875 & 0.583 \\
M1 (p-value) & 0.006 & 0.005 & 0.087 & 0.057 & 0.071 & 0.027 \\
M2 (p-value) & 0.106 & 0.803 & 0.558 & 0.511 & 0.256 & 0.215 \\
\hline
\end{tabular}

Note: ${ }^{*},{ }^{* *}$, and ${ }^{* * *}$ denote significance at $10 \%, 5 \%$, and $1 \%$ respectively. The $M 1$ and $M 2$ test the null of no first-order and no second-order serial correlation in first-differenced residuals.

Source: Authors' calculations based on data from PovcalNet, World Bank and International Country Risk Guide (ICRG) dataset, The Political Risk Services Group. 
The results of the system GMM estimation for Equation 2 (Section 3) that measures the effect of economic growth and institutional quality on income inequality, as well as the results for the Sargan test and the test for serial correlation, are displayed in Table 5. The p-values of the Sargan test lie within the range of around 0.51 and 0.88 , indicating that there is insufficient evidence to reject the null hypothesis of valid instruments. Here again, the null hypothesis of no first order serial correlation can be rejected, but the null of no second order serial correlation cannot be rejected. Therefore, there appears to be no second order serial correlation in the error term of the firstdifferenced equations, suggesting that the GMM estimator would be consistent.

It appears that economic growth does not have an impact on the income distribution since all the coefficient estimates of GDP growth are insignificant (Table 5). This result does not lend support to the Kuznets [7] hypothesis, as well as subsequent studies that have found a positive relationship between growth and income inequality. On the other hand, the absence of a systematic relationship between growth and income inequality corroborates the key findings of Adams Jr. [23, 1], Deininger and Squire [40], and Dollar and Kraay [3]. The finding that growth does not have an impact on the income distribution can be linked to the previous finding that economic growth reduces poverty. Dollar and Kraay [3] revealed that the incomes of the poor tend to rise equiproportionately to growth in average incomes. In other words, they concluded that there was no evidence of a systematic relationship between average incomes and the share of income of the poor (defined as the poorest fifth of the income distribution). Therefore, if economic growth leaves the income distribution unchanged, rising incomes associated with growth would in general improve the poverty situation. For instance, labor-intensive economic growth could provide more jobs, allowing more people to "work themselves out of poverty" [23, p. 20].

The inequality-institutions estimations also give mixed results. While overall institutional quality, government stability, and law and order appear to be insignificant in explaining income inequality, there appears to be a positive and statistically significant relationship between the Gini index and corruption, democratic accountability, and bureaucratic quality. In other words, an improvement in the quality of these three institutional measures tends to worsen the income distribution. These results partly correspond to the mixed findings observed in previous empirical studies on institutions and income inequality. Chong and Gradstein [15], Gyimah-Brempong [43], and Gyimah-Brempong and de Camacho [44] concluded that improvements in institutional quality were associated with falling income inequality. However, Andres and Ramlogan-Dobson [21], Chong and Caldéron [14], and Li et al. [45] claimed that there could be a trade-off between such 
improvements and income inequality in developing countries. System GMM estimation revealed that improvements in the levels of corruption, democratic accountability, and bureaucratic quality could lead to higher poverty levels (Section 4.2). A possible explanation for the increase in poverty levels when the levels of corruption, democratic accountability, and bureaucratic quality are improved is that improvements in these measures lead to greater income inequality, thereby exacerbating the poverty situation.

Chong and Caldéron [19] examined the relationship among five alternative measures of institutions (repudiation of contracts, expropriation risk, corruption in government, law and order, and bureaucratic quality) and the Gini index. They observed an inverted-U shaped relationship for a crosssection of countries from Latin America, East Asia, Africa, and the OECD. Based on their findings, they concluded that for developing countries, improvements in the quality of institutions may be associated with rising income inequality, while for developed countries, such improvements may be accompanied by falling income inequality. Their argument was based on the premise that institutional reform in developing countries may impose high transaction costs on people in the informal or underground sector whose members are not only poor, but also represent a larger proportion of the population.

The informal economy refers to all economic activities that are not covered or are insufficiently covered by formal arrangements, and has been growing steadily in developing countries in the past few decades [62]. Table 6 depicts the share of informal workforce in non-agricultural and urban employment in Africa, Latin America and Caribbean, and Asia. It can be seen that a larger share of the population is employed in the informal sector in Asia (85\%) compared to the other two regions. Furthermore, in Asia, the contribution of the informal sector to GDP is $41 \%$, compared to $29 \%$ in Latin America [62]. Based on their empirical findings, Dobson and Ramlogan-Dobson [63] concluded that in countries where the informal sector accounted for more than one-fifth of GDP, lower corruption could do little to reduce inequality.

Table 6: Share of informal workers employed in 2000

\begin{tabular}{lccc}
\hline Informal workforce as share of: & Africa & Latin America and Caribbean & Asia \\
\hline Non-agricultural employment & $78 \%$ & $57 \%$ & $45-85 \%$ \\
Urban employment & $61 \%$ & $40 \%$ & $40-60 \%$ \\
\hline
\end{tabular}

Source: K. F. Becker, The informal economy (2004), Retrieved from Swedish International Development Cooperation Agency: http://rru.worldbank.org/Documents/PapersLinks/Sida.pdf 
According to Chong and Caldéron [19], institutional reform may involve substantial reductions in the level of red tape and corruption, improvements in tax collection, and additional and more effective training programs for bureaucrats. Initially, such reforms will generate high additional costs on the poor in the informal sector and threaten the very system in which the informal economy operates. Previous mechanisms that made the system in the informal economy work will then no longer be useful and new formal mechanisms will need to be learnt for the survival of the poor, while at the same time such institutional reforms benefit those in the formal sector. Hence, institutional reform may result in higher income inequality in the economy. Notwithstanding, better institutions will eventually improve the efficiency and the effectiveness of public service delivery, leading to lower income inequality $[19,14]$. Developing countries that are assumed to be at the early stages of institutional reform may therefore experience an increase in income inequality as the quality of institutions is improved. Dobson and Ramlogan-Dobson [63] provided a similar explanation for the observed trade-off between inequality and corruption in Latin America. The authors claimed that corruption-reducing policies may impose labor market as well as other regulations that would have an adverse effect on employment and welfare of the informal sector.

The theory advanced by Bourguignon and Verdier [64] may also help to explain the results of Chong and Caldéron [19], as well as the positive relationships between corruption, democratic accountability, bureaucratic quality, and income inequality observed in the present study.

Bourguignon and Verdier [64] examined the link between political influence (democracy) and the distribution of income. They assumed that the economy could be divided into two groups - a rich, educated, and politically active ruling minority, and a poor, uneducated, and politically inactive majority. According to their model, while public decisions are based on majority vote, only the educated minority is allowed to vote. Therefore, as a country is initially run by the educated and politically active people, inequality will increase. In order to achieve higher growth, the education of the less educated and politically inactive majority is subsidized. As a result of subsidization, the ruling minority benefit from a positive education externality. At the same time, however, the rich lose some political control and income as the newly educated individuals are now able to vote and redistribute resources to the poor. Hence, as redistribution policies grow in number, inequality will eventually fall.

Andres and Ramlogan-Dobson [21, p. 972] also argued that corruption may be perceived as "a price worth paying for lower inequality". The authors explained that although the provision of some 
government projects may foster corruption, they would nevertheless help improve the welfare of the very poor. Additionally, even well-intentioned policy makers could hesitate to eliminate corrupt programmes as they may be the only means of improving the conditions of the poor [21].

Based on the coefficient estimates and holding all else constant, a one point increase in the corruption index and democratic accountability index raises the Gini index by 1.06 percentage points, on average. This value is similar to the result of Gyimah-Brempong [43], who found that when corruption increased by one point, the Gini index increased by around 1.54 points. An increase in the bureaucratic quality index by one unit increases the Gini index by 1.36 percentage points.

\section{Concluding remarks and policy recommendations}

Using data from nine developing countries in East and South Asia for the period 1985 to 2009, the present study examines the effect of economic growth and institutional quality on poverty and income inequality. The research questions of the study are as follows: To what extent has economic growth led to a reduction in poverty in East and South Asia? Does economic growth lead to higher income inequality? Has the level of institutional quality had an influence on poverty reduction? What is the effect of institutions on inequality?

The results of the system GMM estimation indicate that growth leaves the income distribution unchanged. Therefore, it is quite likely that growth will be accompanied by a reduction in poverty levels. Although previous studies have also observed that growth is effective in reducing poverty, it is important to emphasize this finding in light of recent debates on the issue and the mixed results reported in the literature. Despite the examination of the growth-poverty relationship in past studies, these previous studies use data from several countries across regions; hence, their elasticities apply to all countries globally. The present study, however, examines the elasticity of poverty reduction for the Asian region specifically and estimates it to be around -4.21 and -6.09 , which is quite high compared to previous global estimates.

Therefore, this study also reveals that poverty can reduce considerably with economic growth in the Asian region compared to other regions. As a result, pro-growth policies should be central to poverty-reduction strategies in East and South Asia. Policies such as openness to international trade, financial development, and macroeconomic stability have been found to leave the income distribution unchanged, and would therefore contribute to poverty reduction [3, 65]. Dollar and Kraay [3, 65] concluded that such policies create a favorable environment for poor households, as 
well as others, to increase their production and income. For example, greater trade openness can increase average incomes that translate into economic growth in the medium term and, in the long run, this can lead to higher productivity and more rapid growth [66].

Nevertheless, it cannot be asserted that economic growth is always be good for the poor or that none of the poor would be badly affected by pro-growth policy reform [67]. This study, then, examines the effect of growth on an aggregate measure of income inequality (the Gini coefficient). On average, it can be concluded that growth tends to leave the income distribution unchanged, and would thus contribute to poverty reduction. However, in view of recent increases in inequality, policies that specifically address the income distribution are recommended. Social assistance schemes are one such strategy that target the poor and can improve the income distribution. According to Walker and Pellissery [68], social assistance schemes in Asia are still comparatively rare. Such schemes must be able to alleviate the consequences of collective and individual crises, prevent a decline in the living standards of the poor, and assist those who face constant vulnerability due to disability, severe illness, old age, or neglect.

System GMM estimation also revealed that improvements in government stability and law and order are found to reduce poverty. But the interesting findings of this study are the positive relationships between corruption, democratic accountability, bureaucratic quality, and poverty and income inequality. This study finds that improvements in these three institutional measures tend to worsen poverty levels and increase income inequality.

Fighting corruption is costly as it uses up resources that could have been utilized more productively elsewhere, and in certain countries, corruption may not be so harmful. Therefore, it is important to analyze and understand the nature of corruption in individual countries before anti-corruption strategies are adopted. On the contrary, in the long term, whether corruption is degenerative or developmental, it will ultimately lead to lower economic growth with the beneficial effects of developmental corruption most likely offset by its negative effects.

Hence, this study recommends that the level of corruption needs to be reduced to ensure sustained economic growth and faster poverty reduction. Similarly, even though the findings of this study indicate that improvements in democratic accountability and bureaucratic quality will increase income inequality and poverty, measures must be taken to improve the quality of institutions. Better quality institutions will encourage foreign direct investment, promoting economic growth and poverty reduction. They can also increase the efficiency and effectiveness of the delivery of social 
services to the poor. At the same time, it is important to adopt policies that specifically address income distribution to prevent any increases in income inequality. However, since institutional reform may impose additional costs on the informal sector, policies that improve the welfare of those in the informal economy and encourage them to move to the formal economy must be implemented. Becker [62] claimed that efforts to reduce poverty would not be successful unless employment needs and the vulnerability of workers in the informal sector are addressed. Therefore, governments should create suitable macroeconomic, social, legal and political environments that foster the "large-scale creation of sustainable, decent jobs and business opportunities" [62, p. 28]. Informal workers must also have access to education, training, microfinance, and such programs must be well-designed and implemented to help these workers move to the formal sector where they are protected by the legal and institutional framework. International donors could also help governments formulate and implement national policies to assist informal workers in the transition to the formal economy, and assist governments by guaranteeing that policies and programs reach the most vulnerable groups [62].

\section{Acknowledgements}

The authors are indebted to valuable comments and suggestions from two anonymous reviewers. 


\section{$\underline{\text { References }}$}

[1] R.H. Adams Jr., Economic growth, inequality and poverty: Estimating the growth elasticity of poverty, World Dev. 32 (2004) 1989-2014.

[2] A.M. Balisacan, E.M. Pernia, A. Asra, Revisiting growth and poverty reduction in Indonesia: What do subnational data show?, Bull. Indones. Econ. Stud. 39 (2003) 329-351.

[3] D. Dollar, A. Kraay, Growth is good for the poor, J. Econ. Growth. 7 (2002) 195-225.

[4] A. Kraay, When is growth pro-poor? Evidence from a panel of countries, J. Dev. Econ. 80 (2006) 198-227.

[5] M. Ravallion, Growth, inequality and poverty: Looking beyond averages, World Dev. 29 (2001) 1803-1815.

[6] M. Ravallion, S. Chen, China's (uneven) progress against poverty, J. Dev. Econ. 82 (2007) 1-42.

[7] S. Kuznets, Economic growth and income inequality, Am. Econ. Rev. 45 (1955) 1-28.

[8] S. Anand, S.M.R. Kanbur, Inequality and development: A critique, J. Dev. Econ. 41 (1993) 19-43.

[9] R. Ram, Level of development and income inequality: An extension of Kuznets-Hypothesis to the world economy, Kyklos. 42 (1989) 73-88.

[10] Asian Development Bank [ADB], Asian Development Outlook 2012: Confronting rising inequality in Asia (2012).

[11] R.H. Wade, Is globalization reducing poverty and inequality?, World Dev. 32 (2004) 567-589.

[12] M._Ravallion, A comparative perspective on poverty reduction, Policy Research Working Paper 5080 (2009).

[13] R.J. Barro, Inequality and growth in a panel of countries, J. Econ. Growth. 5 (2000) 5-32.

[14] A. Chong, C. Caldéron, Institutional quality and poverty measures in a cross-section of countries, Econ. Gov. 1 (2000b) 123-135.

[15] A. Chong, M. Gradstein, Inequality and institutions, Rev. Econ. Stat. 89 (2007) 454-465.

[16] E. Tebaldi, R. Mohan, Institutions and poverty, J. Dev. Stud. 46 (2010) 1047-1066.

[17] R. Hasan, D. Mitra, M. Ulubasoglu, Institutions and policies for growth and poverty reduction: the role of private sector development, Asian Dev. Rev. 24 (2007) 69-116.

[18] X. Sala-i-Martin, 15 years of new growth economics: What have we learnt?, Central Bank of Chile Working Paper 172 (2002), Banco Central de Chile, Santiago.

[19] A. Chong, C. Caldéron, Institutional quality and income distribution, Econ. Dev. Cult. Change. 48 (2000a) 761 186.

[20] P. Keefer, S. Knack, Why don't poor countries catch up? A cross-national test of an institutional explanation, Econ. Inq. 35 (1997) 590- 601.

[21] A.R. Andres, C. Ramlogan-Dobson, Is corruption really bad for inequality? Evidence from Latin America, J. Dev. Stud. 47 (2011) 959-976.

[22] World Bank, Global Economic Prospects 2009: Commodities at the Crossroads (2008).

[23] R.H. Adams Jr., Economic growth, inequality and poverty: Findings from a new data set, Policy Research Working Paper 2972 (2003).

[24] M. Ravallion, S. Chen, What can new survey data tell us about recent changes in distribution and poverty?, World Bank Econ. Rev. 11 (1997), 357-382.

[25] A.K. Fosu, The effect of income distribution on the ability of growth to reduce poverty: Evidence from rural and urban African economies, Am. J. Econ. Sociol. 69 (2010) 1034-1053.

[26] S. Bhalla, Imagine there's no country: Poverty, inequality, and growth in the era of globalization, Institute for International Economics, Washington D.C., 2002. 
[27] F. Fanta, M.P. Upadhyay, Poverty reduction, economic growth and inequality in Africa, Appl. Econ. Lett. 16 (2009) 1791-1794.

[28] R. Ram, Growth elasticity of poverty: direct estimates from recent data, Appl. Econ. 43 (2011) 2433-2440.

[29] R. Eastwood, M. Lipton, Pro-poor growth and pro-growth poverty reduction: What do they mean? What does the evidence mean? What can policymakers do?, Asian Dev. Rev. 19 (2001) 1-37.

[30] J.A. Donaldson, Growth is good for whom, when, how? Economic growth and poverty reduction in exceptional cases, World Dev. 36 (2008) 2127-2143.

[31] S. Basu, S. Mallick, When does growth trickle down to the poor? The Indian case, Cambridge J. Econ. 32 (2008) 461-477.

[32] A. Suryahadi, D. Suryadarma, S. Sumarto, The effects of location and sectoral components of economic growth on poverty: Evidence from Indonesia, J. Dev. Econ. 89 (2009) 109-117.

[33] S.K. Jha, The Kuznets Curve: A reassessment, World Dev. 24 (1996) 773-780.

[34] J. Thornton, The Kuznets inverted-U hypothesis: panel data evidence from 96 countries, Appl. Econ. Lett. 8 (2001) 15-16.

[35] D. Chambers, Does a rising tide raise all ships? The impact of growth on inequality, Appl. Econ. Lett. 17 (2010) 581-586.

[36] J.E. Riggs, J.C. Hobbs, G.R. Hobbs, T.H. Riggs, Kuznets curves stratified by mean per capita income, 1969-2007: Implications regarding global economic development and income inequality, Mod. Econ. 3 (2012) 617-625.

[37] C. Elbers, P. Lanjouw, Intersectoral transfer, growth, and inequality in rural Ecuador, World Dev. 29 (2001) 481 496.

[38] M. Shahbaz, Income inequality-economic growth and non-linearity: a case of Pakistan, Int. J. Soc. Econ. 37 (2010) 613-636.

[39] S.K. Das, A. Barua, Regional inequalities, economic growth and liberalization: A study of the Indian economy, J. Dev. Stud. 32 (1996) 364-390.

[40] K. Deininger, L. Squire, New ways of looking at old issues: inequality and growth, J. Dev. Econ. 57 (1998) 259 287.

[41] M. Ravallion, Inequality is bad for the poor, Policy Research Working Paper 3677 (2005).

[42] S. Gupta, H. Davoodi, R. Alonso-Terme, Does corruption affect income inequality and poverty?, Econ. Gov. 3 (2002) 23-45.

[43] K. Gyimah-Brempong, Corruption, economic growth and income inequality in Africa, Econ. Gov. 3 (2002), 183209.

[44] K. Gyimah-Brempong, S.M. de Camacho, Corruption, growth, and income distribution: Are there regional differences?, Econ. Gov. 7 (2006) 245-269.

[45] H. Li, L.C. Xu, H. Zou, Corruption, income distribution and growth, Economics and Politics, 12 (2000) $155-182$.

[46] Political Risk Services Group, ICRG Methodology (n.d.), Retrieved September 17, 2011, from: http://www.prsgroup.com/ICRG_Methodology.aspx

[47] R.H. Adams, J. Page, Poverty, inequality and growth in selected Middle East and North Africa countries, 19802000, World Dev. 31 (2003) 2027-2048.

[48] A.M. Balisacan, Growth, redistribution and poverty: Is Philippines an exception to the standard Asian story?, J. Asia-Pac. Econ. 5 (2000) 125-140.

[49] M. Ravallion, S. Chen, Measuring pro-poor growth, Econ. Lett. 78 (2001) 93-99. 
[50] K.J. Forbes, A Reassessment of the relationship between inequality and growth, Am. Econ. Rev. 90 (2000) 869897.

[51] C. Hsiao, Analysis of panel data, second ed., Cambridge University Press, Cambridge, 2003.

[52] G.H.Y. Lee, M. Azali, The endogeneity of the optimum currency area criteria in East Asia, Econ. Model. 27 (2010) 165-170.

[53] M. Arellano, S. Bond, Some tests for specification for panel data: Monte Carlo evidence and an application to employment equations, Rev. Econ. Stud. 58 (1991) 277-297.

[54] R. Blundell, S. Bond, Initial conditions and moment restrictions in dynamic panel data models, J. Econom. 87 (1998) 115-143.

[55] A. Levin, C. Lin, C.J. Chu, Unit root tests in panel data: asymptotic and finite-sample properties, J. Econom. 108 (2002) 1-24.

[56] M. Arellano, O. Bover, Another look at the instrumental variable estimation of error-component models, J. Econom. 68 (1995) 29-51.

[57] D.N. Gujarati, Basic Econometrics, fourth ed., McGraw-Hill/Irwin, New York, 2003.

[58] ADB, Poverty in Pakistan: Issues, causes, and institutional responses (2002).

[59] T.P. Soubbotina, K.A. Sheram, Beyond economic growth: Meeting the challenges of global development (2000), The World Bank, Washington D.C.

[60] World Bank, A framework for strengthening access to justice in Indonesia (2007).

[61] A. Wederman, Development and corruption: the East Asian paradox, in: E.T. Gómez (Eds.), Political business in East Asia, Routledge, London, 2002, pp. 34-61.

[62] K. F. Becker, The informal economy (2004), Retrieved from Swedish International Development Cooperation Agency: http://rru.worldbank.org/Documents/PapersLinks/Sida.pdf

[63] S. Dobson \& C. Ramlogan-Dobson, Why is corruption less harmful to income inequality in Latin America?, World Dev. 40 (2012) 1534-1545.

[64] F. Bourguignon, T. Verdier, Oligarchy, democracy, inequality and growth, J. Dev. Econ. 62 (2000) 285-313.

[65] D. Dollar, A. Kraay, Institutions, trade, and growth, J. Monet. Econ. 50 (2003) 133-162.

[66] M. Bussolo, A. Nicita, Trade policy reforms (2009), Retrieved from the World Bank: http://siteresources.worldbank.org/INTPSIA/Resources/490023-1120845825946/Trade.pdf

[67] M. Bruno, M. Ravallion, L. Squire, Equity and growth in developing countries, Policy Research Working Paper 1563 (1996).

[68] R. Walker, S. Pellissery, Giants old and new: Promoting social security and economic growth in the Asia and Pacific region, Int. Soc. Secur. Rev. 61 (2008) 81-103. 


\section{Appendix 1: System GMM estimations with different poverty measures}

Table A1: System GMM estimation results - Poverty gap index (measure of poverty)

\begin{tabular}{lcccccc}
\hline $\begin{array}{l}\text { Dependent Variable: } \\
\text { Poverty Gap Index }\end{array}$ & $\begin{array}{c}\text { Institutional } \\
\text { Quality }\end{array}$ & $\begin{array}{c}\text { Government } \\
\text { Stability }\end{array}$ & Corruption & $\begin{array}{c}\text { Law \& } \\
\text { Order }\end{array}$ & $\begin{array}{c}\text { Democratic } \\
\text { Accountability }\end{array}$ & $\begin{array}{c}\text { Bureaucratic } \\
\text { Quality }\end{array}$ \\
\hline GDP growth & -48.593 & $-13.601^{* * *}$ & $-11.547^{* * *}$ & $-15.817^{* *}$ & -2.883 & 4.143 \\
& $(-1.53)$ & $(-3.27)$ & $(-3.03)$ & $(-2.01)$ & $(-1.24)$ & $(0.32)$ \\
Institutional factors & -1.127 & $-0.144^{* * *}$ & $0.309^{* * *}$ & $-0.424^{* *}$ & $0.518^{* * *}$ & $3.946^{* *}$ \\
& $(-1.46)$ & $(-3.69)$ & $(4.28)$ & $(-2.10)$ & $(3.12)$ & $(2.18)$ \\
\hline Sargan (p-value) & 0.955 & 0.701 & 0.555 & 0.744 & 0.740 & 0.723 \\
M1 (p-value) & 0.019 & 0.054 & 0.078 & 0.034 & 0.016 & 0.031 \\
M2 (p-value) & 0.899 & 0.125 & 0.874 & 0.804 & 0.323 & 0.433 \\
\hline
\end{tabular}

Table A2: System GMM estimation results - Squared poverty gap index (measure of poverty)

\begin{tabular}{|c|c|c|c|c|c|c|}
\hline $\begin{array}{l}\text { Dependent Variable: } \\
\text { Squared Poverty Gap } \\
\text { Index }\end{array}$ & $\begin{array}{c}\text { Institutional } \\
\text { Quality }\end{array}$ & $\begin{array}{c}\text { Government } \\
\text { Stability }\end{array}$ & Corruption & $\begin{array}{l}\text { Law \& } \\
\text { Order }\end{array}$ & $\begin{array}{c}\text { Democratic } \\
\text { Accountability }\end{array}$ & $\begin{array}{c}\text { Bureaucratic } \\
\text { Quality }\end{array}$ \\
\hline \multirow{2}{*}{ GDP growth } & $-35.431^{* * * *}$ & $-20.289^{* * *}$ & $-16.629^{* * * *}$ & $-16.245^{* * * *}$ & 0.370 & 15.368 \\
\hline & $(-3.19)$ & $(-3.89)$ & $(-3.37)$ & $(-3.43)$ & $(0.08)$ & (1.60) \\
\hline \multirow{2}{*}{ Institutional factors } & $0.342^{* *}$ & $-0.160^{* * *}$ & 0.089 & $-0.525^{* * *}$ & $0.360^{* * * *}$ & $3.620^{* *}$ \\
\hline & $(2.313)$ & $(-3.84)$ & $(0.94)$ & $(-5.79)$ & $(3.15)$ & $(2.32)$ \\
\hline Sargan (p-value) & 0.390 & 0.559 & 0.462 & 0.493 & 0.796 & 0.827 \\
\hline M1 (p-value) & 0.077 & 0.079 & 0.048 & 0.083 & 0.053 & 0.003 \\
\hline M2 (p-value) & 0.101 & 0.298 & 0.827 & 0.769 & 0.260 & 0.556 \\
\hline
\end{tabular}

Table A3: System GMM estimation results - Watts index (measure of poverty)

\begin{tabular}{lcccccc}
\hline $\begin{array}{l}\text { Dependent Variable: } \\
\text { Watts Index }\end{array}$ & $\begin{array}{c}\text { Institutional } \\
\text { Quality }\end{array}$ & $\begin{array}{c}\text { Government } \\
\text { Stability }\end{array}$ & Corruption & $\begin{array}{c}\text { Law \& } \\
\text { Order }\end{array}$ & $\begin{array}{c}\text { Democratic } \\
\text { Accountability }\end{array}$ & $\begin{array}{c}\text { Bureaucratic } \\
\text { Quality }\end{array}$ \\
\hline \multirow{2}{*}{ GDP growth } & & $-17.222^{* *}$ & $-12.291^{* * *}$ & $-20.427^{* *}$ & -2.612 & 13.644 \\
& $-19.913^{* *}$ & $(-2.33)$ & $(-2.92)$ & $(-2.33)$ & $(-0.91)$ & $(1.07)$ \\
Institutional factors & $-0.701^{* *}$ & $-0.147^{* * *}$ & 0.277 & $-0.571^{* * *}$ & $0.427^{* * *}$ & $3.574^{*}$ \\
& $(-2.33)$ & $(-3.33)$ & $(3.78)$ & $(-2.66)$ & $(4.23)$ & $(1.84)$ \\
\hline Sargan (p-value) & 0.960 & 0.450 & 0.592 & 0.699 & 0.767 & 0.853 \\
M1 (p-value) & 0.089 & 0.050 & 0.078 & 0.020 & 0.048 & 0.042 \\
M2 (p-value) & 0.142 & 0.233 & 0.690 & 0.592 & 0.576 & 0.895 \\
\hline
\end{tabular}

Notes: ${ }^{*},{ }^{* *}$, and ${ }^{* * *}$ denote significance at $10 \%, 5 \%$, and $1 \%$ respectively. The $M 1$ and $M 2$ test the null of no first-order and no second-order serial correlation in first-differenced residuals.

Source: Authors' calculations based on data from PovcalNet, World Bank and International Country Risk Guide (ICRG) dataset, The Political Risk Services Group. 